\title{
WestVirginiaUniversity
}

THE RESEARCH REPOSITORY @ WVU

Graduate Theses, Dissertations, and Problem Reports

2002

\section{West Virginia University ceramic arts production studio program}

Jeffrey Stewart Greenham

West Virginia University

Follow this and additional works at: https://researchrepository.wvu.edu/etd

\section{Recommended Citation}

Greenham, Jeffrey Stewart, "West Virginia University ceramic arts production studio program" (2002). Graduate Theses, Dissertations, and Problem Reports. 1226.

https://researchrepository.wvu.edu/etd/1226

This Thesis is protected by copyright and/or related rights. It has been brought to you by the The Research Repository @ WVU with permission from the rights-holder(s). You are free to use this Thesis in any way that is permitted by the copyright and related rights legislation that applies to your use. For other uses you must obtain permission from the rights-holder(s) directly, unless additional rights are indicated by a Creative Commons license in the record and/ or on the work itself. This Thesis has been accepted for inclusion in WVU Graduate Theses, Dissertations, and Problem Reports collection by an authorized administrator of The Research Repository @ WVU. For more information, please contact researchrepository@mail.wvu.edu. 


\title{
WEST VIRGINIA UNIVERSITY CERAMIC ARTS PRODUCTION STUDIO PROGRAM
}

\author{
JEFFREY S. GREENHAM
}

\author{
Thesis Submitted to the \\ College of Creative Arts \\ At West Virginia University \\ In partial fulfillment of the requirements \\ For the degree of \\ Master of Fine Art \\ In \\ Ceramics
}

\author{
Robert Anderson, Committee Chair \\ Professor Sarah Smelser \\ Professor Paul Krainak \\ Professor William Thomas \\ Division of Art \\ College of Creative Arts \\ Morgantown, WV \\ 2002
}

Keywords: Ceramics, Pottery, Craft, Production, Techniques 
This thesis is an analysis of West Virginia University's ceramic arts production techniques program, its educational impact, and historical importance. 
ACKNOWLEDGEMENTS - $\quad$ iv

INTRODUCTION -

PROGRAM DEVELOPMENT - $\quad 3$

STUDENT PARTICAPATION -

INTERFACE WITH TRADITIONAL AND INTERNATIONAL
W.V.U. DEPARTMENTAL PROGRAMS -

$\begin{array}{ll}\text { HISTORICAL PERSPECTIVE - } & 10\end{array}$

EDUCATIONAL VALUE OF INCOME GENERATION - 19

W.V.U. / COLLEGE OF CREATIVE ARTS

MISSION ALIGNMENTS -

OUTCOME BASED EDUCATIONAL RESULTS - 28

$\begin{array}{ll}\text { CRITICISM - } & 32\end{array}$

CHALLENGES - $\quad 36$

$\begin{array}{ll}\text { CONCLUSIONS - } & 38\end{array}$

APPENDIX:

A - "Ceramics Department Production Design Center Proposal" - $\quad 40$

$B$ - About the Author - $\quad 46$

$\begin{array}{ll}\text { GLOSSARY - } & 47\end{array}$

$\begin{array}{ll}\text { BIBLIOGRAPHY - } & 48\end{array}$ 


\section{ACKNOWLEDGEMENTS}

The Author wishes to thank the following for their influence and support towards this project:

Dr. Janet Snyder

Catherine, Laurie, and David Greenham

Professor Robert Anderson

Professor Paul Krainak

Professor Sarah Smelser

Professor William Thomas

Dr. Bernard Schultz

The W.V.U. Ceramics Department Staff and Students

West Virginia University

Professor Hobart Cowles

Dedicated To:

Dr. William H. Greenham (1931 - 1999)

For his lifelong commitment to education and creativity; and his unfaltering personal support. 


\section{INTRODUCTION}

In 1997 West Virginia University's (W.V.U.) ceramics department established a Production Studio to offer students real life experience in the tools and demands for running a working ceramics studio. The only department of its kind, the W.V.U. Production Studio gives students the hands on experience in working with production techniques which are often utilized by professional studio potters and small production potteries.

The program is devoted to expanding the students' experience, offering greater preparation to meet the challenges faced by professional studio ceramists in an increasingly competitive marketplace, allowing them the knowledge and ability to more successfully continue working as studio artists and designers following their academic training.

In addition to traditional techniques, W.V.U.'s well equipped studio offers students experience and understanding in the use of plasters for mold making, and semi automated equipment for production of various items.

The Production Techniques Program offers understanding of the unique techniques required to efficiently reproduce designs consistently, through instruction and participation in the department's design, development, and production of items which are marketed and sold. 
The income generated from the sale of work produced through the Production Studio is reinvested into the department. Over the course of the last five years that income has helped to pay for assistantships, scholarships, visiting artists, work study opportunities and new equipment.

The Production Studio is an integral part of the W.V.U. ceramics curriculum. When coupled with the department's large and well equipped facility, general ceramic studies, and the six year old China Exchange program, W.V.U. offers one of the most diverse and expansive ceramics education departments in existence. 


\section{PROGAM DEVELOPMENT}

Since its beginning the West Virginia University ceramics department has, under the direction of Professor Robert Anderson, been a program which placed high emphasis on functional pottery. Over the years many ceramic programs nation wide have moved their emphasis toward more sculptural issues. It has become clear in the last several years that W.V.U.'s commitment to functionally based ideas has made it a leader in programs which offer students educational opportunities to pursue careers as studio potters. ${ }^{1}$

In 1996 the ceramics department at W.V.U. received a donation of a used manual profile jigger machine ${ }^{2}$ from the Homer Laughlin China Co. of Newel, WV. Founded in 1871, Homer Laughlin is the largest domestic pottery employing 1100 skilled workers and most noted as the manufacturer of Fiesta Ware. ${ }^{3}$

Professor Anderson felt this would be a good educational addition to the program and contacted me in 1997 to act as a consultant and look at possibilities to implement a production techniques program. At that time, a proposal ${ }^{4}$ was developed by Professor Anderson, Carmon Colangelo, former Division Chair,

\footnotetext{
1 National Council on the Education of the Ceramic Arts, On site Interviews, 2001, 2002, Conferences, Charlotte, NC; Kansas City, MO Glossary Homer Laughlin Web Site, 2002, http://www.homerlaughlin.com Appendix A, "Ceramics Department Production and Design Center Project", (W.V.U.) 02/1/97
} 
and myself ${ }^{5}$ to start and operate a ceramics production and design center as a related curriculum and businesses activity within the Division of Art.

This proposal, subsequently lead Sergio Soave, Division Chair, to secure start up funding in the form of a grant from the W.V.U. Research Corporation.

"Production Techniques" was in 1998 officially started as a course and several other necessary pieces of equipment including a second jigger/ jolly machine, de-aring extruder were acquired. The Research Corporation grant was also used to fund a graduate assistantship in the fall of 1999.

Since the initial seed money the Production Studio has grown through self sufficient funding generated through two annual studio sales and contract orders. Funding from these areas has been reinvested into the overall program in the following ways:

- Full and part time employment to students

- Student scholarship assistance: W.V.U's summer ceramics program in China

- Additional equipment and material purchases

- Offset of visiting artist costs

- Student assistance towards National Ceramic conference participation

- Departmental promotion

5 Appendix B, About the Author 


\section{STUDENT PARTICAPATION}

Since its initiation in 1998 Production Techniques course has not been considered required course work towards degree completion. Undergraduate and Graduate students who choose to take the three credit hours course are introduced to the various equipment, procedures and processes related to a functioning production pottery environment. From start to finish, from clay making to final glaze firing, students are involved with the various methods required to produce the various items that the production studio designs and creates. During their enrollment in the course students are immersed in the activities of pottery production including:

- Clay Making

- Mold Making

- Throwing

- Jiggering

- Hydraulic pressing

- Trimming and Finishing

- Loading and Firing of Kilns

- Glazing

- Packing of Products for Shipment

- Sale Preparation and Participation

Contact hours are typical of any three credit course and a schedule is developed each semester to evenly distribute student participation throughout each week. 
Students are expected to come and work during their scheduled time on their varied assignments along side the full and part time employees in the studio. They are trained to understand the correct procedures for the assorted processes and expected to take responsibility for the completion of well crafted items.

The course functions much like the long standing tradition of a typical apprenticeship, where the student is given more responsibility as he/she has shown comprehension of the preceding assignments. 


\section{INTERFACE WITH TRADITIONAL AND INTERNATIONAL W.V.U. DEPARTMENTAL PROGRAMS}

West Virginia University's Ceramics program places a strong emphasis on traditional pottery making and the techniques and skills required for students to be sound versatile artist/potters.

The program is studio oriented, encouraging students to form strong design sensibilities and mastery of skills that are associated with strong work ethic and active studio participation. Students are expected to be knowledgeable about historic and contemporary ceramic techniques and trends as well as achieve an understanding of ceramic art history and the implications it has on their own sensibilities. The curriculum stresses the importance for students on all levels to understand the function of all studio-related equipment. Students are expected to be involved in the design and construction of kilns and burners as well as having a command of various firing techniques.

In addition to traditional studies the W.V.U. ceramics program has, for six years, sponsored an annual summer travel and study program in China. Linkage with Chinese ceramic programs provides students with an opportunity to participate, work and interact with Chinese educators, artisans and students gaining valuable 
insight and knowledge of various ceramic processes and techniques as well as a historic perspective of the country responsible for the world's richest ceramic legacy. An ongoing Chinese visiting artist residency program provides our students with an opportunity for a more in-depth experience of traditional and contemporary technique.

The W.V.U. Production Techniques Program, as well, has become a significant element within the overall ceramic arts program offering students the opportunity to engage in a studio production program that introduces them to industrial equipment and techniques. Hydraulic press and jigger-jolly machinery ${ }^{6}$ enables students to learn mold making skills and working knowledge of ceramic producing techniques that are generally associated with industrial ceramic production and often found in professional studios. Students are introduced to these alternative methods of ceramic production that complement strong design sensibilities. Exposure to various marketing strategies and commissions also provides valuable experience that will assist in the successful operation of private studios.

The Production Program's interface with the general and international ceramic studies programming has additionally become an important component to the over all program through its generation of supplementary funding towards

\footnotetext{
6 Glossary
} 
educational, physical and promotional support. The Production Program has offered additional support opportunities through the Chinese visiting artist residency program by producing many items for students of all levels and nonceramic disciplines to participate in visiting artist workshops in decoration and carving. The studio has also become an integral component in design and production of various visiting artist projects. 


\section{HISTORICAL PERSPECTIVE}

The W.V.U. Ceramic arts Production Program is the only one of its kind in this country. My research has identified several programs that are noteworthy for historical comparison and understanding of the uniqueness of the W.V.U. program:

- Berea College, Berea, KY

- Newcomb College, New Orleans, LA

- Graphicstudio, University of South Florida, Tampa, FL

- The Rutgers Center for Innovative Print and Paper, The State University of New Jersey, New Brunswick, NJ

\section{BEREA COLLEGE}

Currently in the United States the only comparative ceramics program is located at Berea College, Berea, KY.

In 1893 Berea's College President William G. Frost began "Fireside Industries". The initiation of this program added weaving as the first in a line of Appalachian craft revival programs to join the already self-sustaining community, complete with College-operated farms, dairy, bakery, brick factory, hospital, and fire department. This was eventually followed by a woodworking production division developed out of the cabinetry program. By the mid 1900's most of Berea's programs shifted away from its self-sustaining curriculum in agriculture. The "Fireside Industries", however, shifted more toward crafts production for a range of retail markets. The College, in conjunction with the Southern Highland Craft 
Guild, moved to create a market for quality regional crafts in the traditional sales centers of Berea, Gatlinburg, and Asheville, with expansion including shipments to the entire nation. ${ }^{7}$ In 1970 , Berea's ceramics department became the Ceramic Apprenticeship Program, a formal crossover between classroom and practical work experience. Currently almost 200 students and 25 full-time staff work in the Student Crafts Program, making and marketing the wood, brooms, weaving, iron, and pottery. Two shops in Berea - the Log House Craft Gallery and the Boone Tavern Gift Shop - are student staffed. Over the years the Berea program has successfully trained dozens of young studio potters who have continued on to develop their own professional studios. ${ }^{8}$

Today, the Berea program continues to offer a simple line of hand thrown pottery and currently does not deal with any cross over industrial or semi automated production equipment. The work continues to be sold through regional outlets, catalog sales, and has recently expanded to include internet sales through the department run web site. ${ }^{9}$ Apprentices work 10 to 20 hours a week, and as with a wide range of curriculum programs at Berea these hours are used to offset tuition costs. ${ }^{10}$ Berea's program is partially funded through the sales of the work made there with additional financial support from the College is obtained through grants and private support.

\footnotetext{
7 Warford, Malcom L. "Coopting the Counter Culture: the Making and Unmaking of a Radical Tradition at Berea College (S.I.:s.n.) 1974

Baker, Jerry, "No Childs Play: Berea College and the Appalachian Hand Craft Revival", Sunshine Artist, 1998

9 Berea Crafts Online Catalog, 2002 http://www.bereacrafts.com

10 Berea College Web Site, 2002 http://www.berea.edu/
} 


\section{NEWCOMB COLLEGE}

Founded in 1882 Newcomb College at Tulane University was the first degreegranting women's coordinate college in the nation, and the Newcomb/Tulane model was later emulated by institutions such as Pembroke/Brown and Barnard/Columbia. The New Orleans, LA, based Newcomb College stressed an education both "practical and literary". The Art Department would become the focus of this institutional ideal. ${ }^{11}$

Among the young faculty hired to develop Newcomb's program of art education was Ellsworth Woodward, who brought with him traditions he learned at the Rhode Island School of Design. Woodward envisioned an ambitious program of vocational training for young women artists. ${ }^{12}$ Under his guidance, Newcomb Pottery was established in 1894 after Mary Given Sheerer arrived from Cincinnati Art Academy to teach pottery and china decoration. ${ }^{13}$

Based on the visions of Sheerer and Woodward, the distinct wares of Newcomb Pottery became well known in the art world of the day. The students and graduates worked with designs evocative of the American South, inspired by Louisiana flora and crafted from local and regional clay. As the twentieth century opened before them, some students moved towards developing more modern

\footnotetext{
11 Tulane University Web Site, 2001, http://www.2.tulane.edu/about_history.cfm 12 Levin, Elaine, The History of American Ceramics, (Harry N. Abrams, Inc. ,NY,NY))1998,99105 13 Levin, Elaine. The History of American Ceramics, (Harry N. Abrams, Inc., NY,NY), 1998,99-
} 
designs, yet still maintained the philosophy that no two pieces of pottery should be alike. ${ }^{14}$

During nearly fifty years of operation, Newcomb Pottery provided employment to roughly ninety Newcomb graduates, and produced some 70,000 distinct pieces of work. Newcomb Pottery is considered one of the most significant American art potteries of the first half of the twentieth century. Influenced by the English Arts and Crafts movement, Newcomb pottery was exhibited around the world, sold in shops on both coasts, and written about in art journals throughout the United States and Europe. Newcomb potters (always men) and designers (always women and girls) were awarded eight medals at international exhibitions before 1916. The Newcomb Pottery as an education/entrepreneurial division of the ceramic arts program at Newcomb College ceased operation in1944 as a result of declining division enrollment and sales. ${ }^{15}$

Louisiana State Museum Web Site, 2001,http://www.Ism.crt.state.la.us/newcomb1.htm/birth Newcomb College, "100 Years of Ceramics at Newcomb College,1894-1994:a faculty retrospective(Newcomb College Art Department, New Orleans, LA)1994 


\section{GRAPHICSTUDIO}

Founded in 1968 by University of South Florida, College of Fine Arts Dean, Donald J. Staff, Graphicstudio has offered participating artists a wide range of resources and opportunities for research. It has hosted some of the most talented contemporary artists in the world to collaborate not only in the areas of printmaking but additionally in sculpture and other forms of art making. ${ }^{16}$

Graphicstudio trains students for professional careers in the arts, who have gone on after graduation to be artists, curators, gallery owners and printers. This training is accomplished through several student opportunities:

- Graduate Assistantships through the USF Art Department

Graduate students from the Art Department at USF spend semesters working with the highly skilled faculty at Graphicstudio, developing their professional skills.

- Internships

Undergraduate and graduate students from the University of South Florida and other institutions may apply for internships in several different areas, for institutional credit and practical instruction. Included are opportunities to work in Production, assisting with printmaking or sculpture fabrication, or in Curatorial techniques where they can learn the fundamentals of paper handling, conservation and exhibitions preparation.

16 Tabor, Sandy, http://www.graphicstudio.usf.edu/news, Graphistudio at U.S.F., Press Release, 3/18/99 
- For-credit classes

USF offers instruction in printmaking history and techniques.

- Technical workshops

Technical Workshops further the knowledge of art students and professionals from around the world in advanced printmaking processes and new printmaking techniques. ${ }^{17}$

- Colloquia

Colloquia such as the "Block Prints in the Americas Colloquium", have gathered together experts from all over the world to examine technical, critical and art historical aspects of a single technique.

- Lecture Series

Lectures by visiting Graphicstudio guests offer the community the opportunity to hear artists, curators and printmakers talk about their work, ideas and careers. ${ }^{18}$

The Graphicstudio program continues its educational and professional activities through a diversified balance of funding sources. As a master print center, various contracts are negotiated with individual artists for the financial support of the program either through sale of prints or fees paid by the individual artists. Additional funding support is obtained through regular and continuing University support, various grant procurements, and the publishing of technical journals and video tapes dealing with ongoing research at the center.

\footnotetext{
17 Graphicstudio at U.S.F. Web Site, 2001, http://www.graphicstudio.usf.edu

18 Graphicstudio at U.S.F. Web Site, 2001, http://www.graphicstudio.usf.edu
} 


\section{RUTGERS CENTER FOR INNOVATIVE PRINT AND PAPER}

The Rutgers Center for Innovative Print and Paper (RCIPP) was founded in 1986 by Judith K. Brodsky as an international, national and regional center for leading edge printmaking ideas and education. As part of Mason Gross School of the Arts, Rutgers, The State University of New Jersey, located in New Brunswick, $\mathrm{NJ}$; RCIPP is a learning center where students serve as interns and work with the master printers and papermakers. ${ }^{19}$

The RCIPP offers graduate and undergraduate programs in the Department of Visual Arts, Mason Gross School of the Arts. Both undergraduate and graduate students serve as interns and assistants at the RCIPP helping the printers in artist collaborations and in printing editions. If they qualify, the RCIPP will also accept other individuals interested in learning more about print and paper processes as assistants.

RCIPP also offers short term workshops in both new and traditional printmaking techniques. These are generally held during the summer, and offer university housing for participants. ${ }^{20}$

19 Rutgers Center for Innovative Print and Paper Web Page, 2001 http//www.rcipp.rutgers.edu/default.html

${ }_{20}$ Rutgers Center for Innovative Print and Paper Web Page, 2001 http//www.rcipp.rutgers.edu/default.html 
The overall RCIPP program is primarily funded through the Mason Gross School of the Arts with additional funding from regional and national grants, as well as private support.

It is clear that all these programs each in their own way have been educationally important and historically influential either regionally or internationally. In reviewing these programs many parallels can be found with the relatively young W.V.U. ceramic Production Program and in all of the referenced programs there are a number of issues that are found to be consistent:

- All of the programs are educationally based in both their initial development and ongoing opportunities for students.

- All of the programs are educational entrepreneurial models with a segment of their operational costs being generated from either sales of products or contractual agreements.

- Student participation in these entrepreneurial / professional settings has or is considered to be an important educational tool by all of the exampled institutions and in many cases has proved its importance in the outcome based results of students continuing on to professional careers in related areas.

- All of the exampled references have successfully continued their programs for substantially long periods through balanced support both financially and 
administratively from their individual institutions as well as through program income generating initiatives.

- All of the programs have impacted their fields regionally or nationally through their education, programs, research and sales.

- Many of the programs have affected their regional communities through economic development, employment, educational outreach, and lecture programs. 


\section{EDUCATIONAL VALUE OF INCOME GENERATION}

As a required consideration in the initial proposal of early $1997^{21}$, the W.V.U. ceramic arts Production Studio has sought to develop financial self sufficiency and not seek funds from the Division of Art on a regular basis.

This requirement has been achieved through primarily two sources:

- Twice each year a studio sale is advertised and operated. This is a common practice in many collegiate ceramic arts programs. The sales at W.V.U. offer students an opportunity to participate in the understanding of what is involved in the sale of their own work from set up to customer service. Students are paid $50 \%$ of the retail price of their work and the remaining $50 \%$ is reinvested in the department. This is again a typical practice nationwide and modeled much like the professional sector of the wholesale contemporary crafts market.

The W.V.U. ceramics department sales are also the primary outlet for work produced through the production studio and accounts for upwards of $70 \%$ of the sales at each event. A small percentage of work is also sold through the sales produced by ceramic artists outside of the program. To this point this has been work primarily by one supplier, Porcelain artist Bill Campbell. Campbell has a personal interest in the uniqueness of the WVU production program and has offered support in several ways including sending pieces on a 50/50 consignment basis for the studio sales.

21 Appendix A, Proposal, "Ceramics Department Production and Design Center Project", (W.V.U.) 02/1/97 
- The other area of funding generation for the production studio has been through contract work. Projects in this area have varied from client to client including, commemorative plates, coffee mugs, serving bowls and pizza stones. The program has recently started handling some wholesale accounts within the state of West Virginia.

From its introduction in 1997 through September of 2001 the West Virginia University Ceramic Arts Production Program has generated over $\$ 87,000.00$.

The reinvestment of those funds has been distributed back into the W.V.U. ceramics program as follows: ${ }^{22}$

Labor -

Student proceeds from semi annual sales -

Semi Annual Sale Supplies -

Semi Annual Sale, Wholesale vendor payments -

Student Scholarships, China Program -

Visiting Artists -

NCECA 2000 -

Graduate Assistantships -

Materials -

TOTAL -
$23.25 \%$

$26.73 \%$

$3.21 \%$

$3.56 \%$

$7.00 \%$

$10.00 \%$

$8.00 \%$

$13.95 \%$

$3.40 \%$

$100 \%$

22 Anderson, Professor Robert, (Information source), November, 2001 
The line item details of the above distribution are as follows:

LABOR: represents costs associated with the employment of one full time worker and intermittent part time workers within the production studio. A full time employee (former student) was hired in 1999. Part time workers have typically been students or graduates hired for short periods outside of the academic year.

STUDENT PROCEEDS FROM SEMI ANNUAL SALES: represents the $50 \%$ payment for sales of student produced work.

SEMI ANNUAL SALE SUPPLIES: represents miscellaneous costs associated with the semi annual Christmas and Spring sales. This includes the costs for food, advertising, shopping bags, etc.

SEMI ANNUAL SALE, (WHOLESALE VENDOR PAYMENTS): represents wholesale payments to professional artists whose work is sold at the W.V.U. sales.

STUDENT SCHOLARSHIPS, CHINA PROGRAM: represents scholarship funding to W.V.U. students who work in the production studio on a part time basis as a means of offsetting a portion of the costs associated with their participation in W.V.U. annual summer ceramics program in China.

VISITING ARTISTS: represents costs associated with bringing visiting artists to W.V.U. To date this has involved primarily visiting artists from China and has covered the majority of costs such as air fair, food and housing. 
NCECA 2001: represents costs associated with the 2001 National Conference on the Education of the Ceramic Arts in Charlotte, NC. These costs included transportation and hotel accommodations for graduate and undergraduate student participation in the conference; W.V.U. promotional table, production and printing of W.V.U. promotional materials including posters and brochures profiling the W.V.U. ceramics program and the W.V.U. summer ceramics program in China.

Additional costs included production costs associated with the "Shared Journeys: Chinese and American Ceramics" exhibition curated by Professor Robert Anderson and W.V.U. graduate students and representative of artists who have participated in the W.V.U. summer ceramic program in China. NCECA 2001 was the initial stop on a four site itinerary ${ }^{23}$ for the exhibition and costs included exhibition transportation and exhibition equipment including the costs associated with building of pedestals and partitions, printing of accompanying photographs and signage.

GRADUATE ASSISTANTSHIPS: represents costs associated with a graduate assistantship during the 2000 academic year.

MATERIALS: represents costs associated with the purchase of raw materials in the form of clay and glaze materials for the production program and includes

\footnotetext{
23 "Shared Journeys: Chinese and American Ceramics from the W.V.U. Program" Itinerary: Winthrop University Rock Hill, SC (NCECA 2001); Logan Gallery, Chautauqua, NY; Huntington Museum, Huntington, WV; Paul Messaros Gallery, W.V.U., Morgantown, WV
} 
costs of fire brick and additional kiln building materials for the W.V.U. ceramics program as a whole. 


\title{
W.V.U. / COLLEGE OF CREATIVE ARTS
}

\author{
MISSION ALIGNMENTS
}

As in any situation it is important that a given program within an organization fit the short and long range plans associated with the parent organization. In reviewing the Mission Statement of W.V.U. and its applications in relation to the Production Studio program, it is clear that the program has multiple alignments with the University's overall mission, the strategic plans within the College of Creative Arts, and the University's research areas. Specifically within the W.V.U. mission statement several areas are significant to the Production Studio program: $^{24}$

- Ability for students to acquire the essential knowledge and skills in their majors to excel in their careers or to succeed in graduate or professional schools. ${ }^{25}$

The WVU ceramic arts Production Program when coupled with the department's traditional ceramics studies and the summer China Program, offers one of the most diverse ceramic arts educations in North America. ${ }^{26}$

- Gain hands-on exposure to the latest technology in their areas of specialization. $^{27}$

WVU Mission Statement http://www.wvu.edu/vision.html, 2001

WVU Mission Statement http://www.wvu.edu/vision.html, 2001

National Conference on the Education of the Ceramic Arts, Ceramics Program Database, http://www.nceca.net/schools.html.

${ }_{27}$ WVU Mission Statement http://www.wvu.edu/vision.html, 2001 
The Production Program offers students, through the use of jigger/jolly and hydraulic press equipment, hands-on experience with technologies traditional to industry and evermore commonly used by studio potters.

- Graduate teaching programs and research efforts are focused for excellence, impact and reputation. ${ }^{28}$

The ceramics program, again through its diversity and strong emphasis on traditional pottery making and the techniques continues to carry a sound reputation nationally for producing ceramic artists/potters, both graduate and undergraduate, with strong versatile skills.

- Opportunities to conduct pioneering research and scholarship help attract high quality faculty and students. ${ }^{29}$

The Production Studio continues to be involved with a number of research projects interfacing the WVU ceramics program's visiting scholars and artists from China. There is additional potential, through its ability to produce multiple items efficiently, and increasingly well equipped center, to enter into interesting projects with further artists and scholars from both ceramic and cross disciplinary backgrounds. The program has been recently spotlighted to a national audience of federal and state legislators for its research achievements. The numerous opportunities for research and scholarship both within and outside W.V.U. and the program's uniqueness offer attractive opportunities for students and faculty. 
- Develop a capacity to conduct research that enhances West Virginia and meets the state's "new economy" needs.

The Production Program's uniqueness and ongoing research enhances West Virginia nationally. The entrepreneurial nature of the program also helps to meet the state's "new economy" needs through meeting the states request of the University towards application of entrepreneurial programs and reinvestment of "intellectual transfer"31 through the sale of its pottery to expand the educational opportunities for students beyond the state budget abilities.

Within the College of Creative Arts the Production Program continues to advance the college's strategic priorities.

The growing interface between the Production Program and the department's international exchange with China have helped expand the Division of Art's leadership in international programs. The WVU ceramics program in China was cited as a premier international study program at the 2001 N.C.E.C.A. conference in Kansas City, Mo. ${ }^{32}$ The Production Program has contributed support of this international exchange program through financial and educational

30 WVU President's State of the University Address, http://www.wvu.edu/ presoffc/sofu2000.htm 31 Weete, John, D., "Overview of Research at WVU" (WVU, Research Corp., Morgantown, WV) http://www.wvu.edu/ research/research-plan.html, 2001

${ }_{32}$ National Council on the Education of the Ceramic Arts, audience participant, Panel Discussion: After Celadon: A Look at Ceramics in China Today - Caroline Cheng [m], Chen Guang Hui, Wayne Higby, Jiansheng Li, March 15,2001, Kansas City, MO 
assistance helping to meet the challenges by the C.C.A. for leadership in international programs. ${ }^{33}$

The program continues to meet the College's plan by offering students education and experience with techniques and processes commonly found in professional studio practice offering further student support towards achieving professional goals. ${ }^{34}$

The Production Program additionally addresses the plan in its role as an income generating program playing a role in the economic life of the University ${ }^{35}$, community, region and state through its sales locally, support to community nonprofit organizations, wholesale purchase of the studios products by West Virginia owned retailers, and promotion of the programs at West Virginia University.

33 Strategic Plan 2001-2006, Draft, (College of Creative Arts, West Virginia University, Morgantown, WV), 2001

${ }_{34}$ Strategic Plan 2001-2006, Draft, (College of Creative Arts, West Virginia University, Morgantown, WV), 2001

35 Strategic Plan 2001-2006, Draft, (College of Creative Arts, West Virginia University, Morgantown, WV), 2001 


\section{OUTCOME BASED EDUCATIONAL RESULTS}

The relative newness of the W.V.U. Production Program offers little direct evidence of its educational importance in terms of post degree effects for students. Research for this document has identified a number of professional trends which may help in forecasting the program's long range educational importance.

Founded in 1953, Ceramics Monthly is the world's oldest, most comprehensive and largest ceramic art periodical, an internationally distributed magazine on ceramic art and craft. ${ }^{36}$ In 1992 Ceramics Monthly was purchased by the American Ceramic Society of Westerville, $\mathrm{OH}$. The American Ceramic Society (ACerS) is the world's leading non- profit organization dedicated to the advancement of ceramics.

ACerS provides the latest technical, scientific and educational information to its Members and others in the ceramics and related materials field and has been the historical clearing house for the ceramic industry. The move by ACerS to purchase Ceramics Monthly, subsequent development of Pottery Making Illustrated, and the Potters Council of the American Ceramics Society ${ }^{37}$ is a significant event. As the most important international ceramic industry related 
organization, these developments indicate the growing and closer relationship between the ceramic industry and studio artists.

In 2000 B.N.P. Publications, publisher of the ceramic industry's leading trade publication Ceramic Industry, introduced a new publication supplement Pottery Production Practices ${ }^{38}$. As the most prominent international commercial publication for the industrial community the addition of this publication indicates the increasing demand for information related to production techniques and practices by the studio ceramics community.

The contemporary craft community as a whole has seen a historical expansion over the last twenty five years. In a 2001 survey by the Craft Organization Directors Association (CODA) this growth and its significant contribution to the national economy was documented. The CODA survey found that the American craft community currently represents a $\$ 14$ billion industry. Of the estimated 127,000 craft artists, $64 \%$ work alone and have a mean annual income of $\$ 22,000$. $^{39}$

The CODA survey indicated that the mean annual income for ceramic artists was $\$ 29,000$ slightly higher than the overall average, however well below the $\$ 40,800$ national household average.

38 Pottery Production Practices, (Business News Publications, Troy, MI.), March, 2000 
Of the $36 \%$ of artists who utilized employees the annual mean income rose to $\$ 56,041$. Many of these artists have found that while retail shows may statistically be most popular sales venue, wholesale markets generate more annual revenue. $^{40}$

For the studio crafts person the development of a number of wholesale markets within the last fifteen years has played a major role in the maturity, growth and sophistication of the contemporary crafts world of today.

These changes in the market have evolved into a highly competitive environment for working studio artists. Studio craftspeople are required to meet the professional challenges if they wish to continue with their work by presenting well crafted, well designed work. This professionalism carries through to producing consistent lines of work, designed and created to offer unique ideas in a landscape full of options both hand crafted and industrially made. Through its own success the growth and popularity of American crafts has reached a point where the division between handcrafted and industrially produced has become vaguer and the competition keener.

To that end, it is becoming more and more common to find traditional industrial equipment, of the style that the W.V.U. Production Studio has implemented, in the production studios of individual professional ceramic artists. ${ }^{41}$ Artists have found uses for this "outdated" industrial equipment to solve a number of problems from efficiency to consistency that face them in this challenging market place. In

40 "CODA Survey Results", The Crafts Report, (Wilmington, DE), May, 2001

41 Edgecomb Potters, Catalog, (Richard Hilton, Edgecomb Potters, Edgecomb, ME)2000 
some cases it has enabled them to expand their businesses and increase their income by meeting the challenges of the market place. In many cases they have used the equipment to investigate new design concepts that are too complicated to reproduce solely by hand and which allow them to offer unique work to the complex marketplace. ${ }^{42}$ Strong design sensibilities and mastery of traditional skills remain key to success artistically and professionally, and continue to be fundamental to the W.V.U. program.

The evidence found in both the private and non-profit sectors of the ceramic art field indicates a continuing move and interest by many studio artists to employ the use of the same types of equipment and technologies used in the W.V.U. Production Studio program, and W.V.U. remains unique in the education of the these alternative methods of ceramic production and the techniques associated with them.

42 Campbell Studios, Inc., Catalog, (Bill Campbell, Campbell Studios Inc, Cambridge Springs, PA) 2000 


\section{CRITICISM}

The Production Program at W.V.U. has met with some professional criticism within the scholastic community for the idea of teaching the use of semi automated equipment in a studio art program. The argument rests on the ideals that through their use the maker's hand is removed from the artwork.

This is not a new argument, and dates back to the late 1800's with the English Arts and Crafts movement's rejection of the machine in favor of a return to handcrafts. American artists / educators like Charles Binns, founder of the Alfred University program, ${ }^{43}$ and architect Frank Loyd Wright defended the ideas of quality and design in an effort to straddle the concurrent movements of the Arts and Crafts and the Industrial Revolution. In 1893 an attempt was made to form an association of art and industry, however the American Arts and Crafts Movement, then at its height, made any affiliation with industry unthinkable. ${ }^{44}$

The argument was reiterated again in the late 1950's with the roots of "back to the earth" movements; however by then the beginnings of the American Pop Art movement affected ceramic art programs where slip casting as a semiautomated process for producing multiples was in full swing. ${ }^{45}$

43 Carney, Margret, "Charles Fergus Binns: The Father of American Studio Ceramics",(Hudson Hills Press, NY,NY), 1998

${ }_{44}$ Levin, Elaine, "The History of American Ceramics: 1607 to the Present",(Harry N. Abrams, Inc.,NY,NY)1988, 129

${ }_{45}$ Levin, Elaine, "The History of American Ceramics: 1607 to the Present",(Harry N. Abrams, Inc.,NY,NY)1988,186 
The argument continues today in some ceramic circles and clearly has no end or right and wrong. The decision of tools clearly rests on the shoulders of individual artists and individual choices for artistic necessity. The argument aside, it is clear that the use of semi-automated equipment fits the changing needs of a growing number of studio potters. It is important to note that the W.V.U. program at its heart is dedicated to a strong emphasis on traditional pottery making and the techniques and skills required for sound versatile artist/potters and the education of diverse tools only augments that mission. In light of the shifting climate in studio production ceramics, it seems clear that the W.V.U. initiative offers education of alternative methods of ceramic production complementing strong design sensibilities is insightful. It should also be noted that the W.V.U. Production Studio, in its training, highlights the versatility of these tools, using them to not simply recreate the same item, but by producing what might be best described as blanks which can then be altered to bring individuality to each piece. Even with the exclusion of wheel throwing or hand building procedures the artist's hand and vision are still in control and essential.

The W.V.U. Production Studio has also fallen under some criticism for generating income on the shoulders of students. There is some misunderstanding surrounding this criticism. Although students participate in the making of ware which is then sold, their involvement is limited to the three credit "Production Techniques" course. The primary focus of this class is for students to learn and 
understand the production techniques and equipment within the production studio. As with any course the students involved have various levels of skill when they arrive and need time to learn the proper procedures. The vast majority of the work produced for sale is primarily made by the staff of the Production Studio and although students participate in that process their limited time within the studio requires that the staff completes much of the student work.

When weighed against the education benefits both participatory and financial, student growth in areas of techniques, craftsmanship, design and expanded opportunities, the issues of profit soundly lies on the side of the student.

Some trepidation has arisen from college administration regarding the Production Studio being too personality driven. ${ }^{46}$ Certainly Professor Robert Anderson's initiative and continuing passion for the Production Program is its driving force. In reviewing comparative and historically related programs, it has been observed that in all cases these programs have required a strong personality to carry them forward in terms of ideas, planning and reality. The long term strength, however, necessitates a formal administrative commitment to the idea and program alignment with the mission of the organization as a whole. In researching data for this document it seems clear that the W.V.U. Production Program meets the mission of the University and the College. The initial securing of seed funding to the program by the College constitutes commitment. It must be therefore

46 Schultz, Dr. Bernard, Dean, W.V.U. College of Creative Arts, Interview, October, 2001 
assumed that if further support, both moral and fiscal, continues to be addressed by the administration that the long range welfare of the program is secure even as personalities ultimately change. 


\section{CHALLENGES}

The current major challenge facing the W.V.U. Production Studio is related to space. At its inset the obvious limited space was a concern and after several years of operation and growth the space issue has become critical as the program's success has squeezed the personal working space available to some students. The department and the administration are presently looking at several options to alleviate this problem. In all cases these potential solutions require the leasing of private off campus space. It is assumed at this time that a solution will be resolved in the near future.

The new issues that will face the Production Program resulting from such a move will include increased overhead from rent, utilities and transportation of raw materials. These concerns will require additional support either through increased employee labor and sales, or increased University funding for the Production Studio to continue its financial support of programming with the same diversity and levels that it currently sustains.

The interface between the Production Program, traditional studies, and the international China exchange program are critically important in the overall education format of the ceramic arts program at W.V.U. Financial support from Production Program revenues have offered substantial economic support to the international studies program, departmental publicity, and educational support. In light of the proposed move of the Production Program and the resulting financial 
pressures, alternative support should be more aggressively sought to absorb some of these costs, thereby offsetting some of the new overhead pressures.

New changes in bookkeeping practices have resulted in income from the Production Studio being deposited in a State account. Understandably this change was necessitated to assure proper reinvestment of funds. This change has created problems in relation to student participation and reimbursement from the sale of student work by requiring that all participating students be treated as employees and payroll taxes be deducted from their payments, no matter how small. With student participation in the bi-annual sales being an important educational experience and adding important program interest and support by the general public, a solution to this problem needs to be addressed.

Recent West Virginia University B.F.A. graduates have commented that more formal training in business practices and marketing would be a valuable tool. This remark has also been reiterated by potential students at national ceramics conferences. Based on these observations and input from a number of professional studio ceramicists, investigation of educational opportunities in these areas should be considered. 


\section{CONCLUSIONS}

In review of the W.V.U. Production Studio program it is clear that the educational value is credible. The program continues to meet the challenges set forth by the State, the University, and the College, through its educationally based programming.

The program also meets the challenges of the University by meeting the "New Economy" realities through its self reliant funding programs. Through its support the program has offered students valuable educational opportunities in International studies and National conference participation beyond the fiscal means of the College and University.

It is clear that the Production Program, as an integrated component of the overall ceramic arts programming, has created a unique and increasingly respected program on a national level. It can therefore be envisioned that through commitment and refinement the program will be useful in continuing to attract strong students to W.V.U.

There is no question that untapped potential lies in many areas which the program can address, from business studies to artistic diversity. The meeting of 
that potential will require on going insight, planning, and support by faculty and administration to reach its full maturity and the potentially important aspects of the program's overall long range success.

In light of the ever changing professional realities, the Production Program addresses current education issues by staying abreast of the trends and technologies affecting contemporary studio potters. Continued foresight will be necessary towards meeting these changing educational needs and offering strong professional training.

If W.V.U.'s own history can be considered a barometer for the future of the ceramics Production Program, it can be assumed that the same unique and insightful vision that helped develop W.V.U.'s summer ceramic experience in China into a leading program nationally, with a growing list of similar opportunities now offered by other institutions; one can envision the W.V.U. Production Studio program also influencing ceramic departments on a National level. 
Appendix - A

\title{
West Virginia University College of Creative Arts Division of Art
}

\section{Ceramics Department Production and Design Center Project:}

\author{
A Proposal to develop and operate \\ a Ceramics Production and Design Center \\ as a Related Curriculum and Businesses Activity \\ within the Division of Art
}

February 1, 1997

Prepared by: Prof. Robert Anderson

Carmon Colangelo, Dept. Chair

Jeff Greenham

\section{Introduction / Overview}

The Production and Design Center (PDC) will be an integral part of the curriculum for Master of Fine Arts, Bachelor of Fine Arts programs, and will provide enrichment for all other visual arts programs and levels. The 
development of the Center is the result of the research and vision of Professor Robert Anderson.

The Production Design Center (PDC) would be the only program of its kind available in the western world. Many institutions offer degree programs in ceramic arts through the use of relatively ancient techniques, but do not offer facilities or the essential actual experience in the use of newer technologies for the development or production of new concepts and designs. The (PDC) would not only expand the experience of students, but additionally enhance the presence of W.V.U.'s Arts Division program nationally, attracting a larger base of potential students.

The PDC will be fully contained within the Division of Art and The College of Creative Arts and will not represent a "stand alone" center or institute. The PDC will not seek funds from the Division of Art on a regular basis and will become a self sustaining entity.

Professor Anderson, through a developing relationship with The Homer Laughlin China Co. of Newell, WV, has obtained some of the equipment required for the initial development of the project. Additionally, Professor Anderson has obtained the services of consultant Jeff Greenham, well versed in the area of studio ceramics business and production, through existing Ceramics Department funds; however these funds will be depleted within the early development stages of the project.

This proposal represents a request for base budget support in the form of a "Director" position and to cover general start up expenses and support for the PDC.

Professor Anderson and Mr. Greenham have worked jointly with College of Creative Arts, Dean Philip Faini and Division of Art, Chair Carmon Colangelo to develop the Mission of the program and proposals for it's implementation.

\section{Mission Statement}

The mission of the Production Design Center is to expand the experience of students to include the use of industrial techniques, production equipment and, business tools for the development, production and marketing of ceramic products.

The program would expand the experience of students to better prepare to meet the challenges faced by studio artists in the increasingly competitive marketplace, allowing them the knowledge and ability to more successfully work as studio artists and designers. 
The program would require students to understand the unique techniques required to efficiently reproduce designs consistently, through instruction and participation in the department's design, development and production of items to be marketed an sold in an effort to supplement the costs of the program.

\section{Plan to Develop, Produce and Market Ceramic Products}

Professor Robert Anderson has recently obtained the services of Mr. Jeff Greenham, an expert in the area of Studio Ceramics production and business on a per diem basis from existing, but limited, Ceramic Department funds.

We wish for Mr. Greenham to direct the PDC program, train students and apprentices, oversee all aspects of the development, production and marketing of a line of ceramic ware on our campus.

This production would be sold, with the proceeds to benefit the PDC and related activities within the division of Art.

Professor Robert Anderson, in consort Mr. Greenham, would be ultimately responsible and involved in the operation of the PDC.

\section{Proposed Model for Start Up and Operation}

The proposed model for the development and implantation of the Production Design Center (PDC) involves the following three phases and proposed Time frames.

PHASE 1. Proposed Time Frame - 8 weeks

\section{DEVELOPMENT}

\section{A. Identification and Research of Existing Market Capabilities}


Professor Anderson and Mr. Greenham have already identified W.V.U. Alumni Magazine, W.V.U.'s chain of Bookstores, and The Tamarack Crafts store in Beckley, WV as initial target markets for the start-up period of the PDC. Products would be designed with an orientation to best fit markets.

\section{B. Facility Set Up}

Utilizing existing space within the Ceramics Department the installation of the some new and recently acquired equipment (donated by The Homer Laughlin China Co.) will be completed.

This equipment includes, but is not limited to: Deairing Mills, Batter-out machine, Jigger / Jolly machines, plaster mold making equipment, and shelving.

\section{PHASE 2. Proposed Time Frame - 10 - 12 weeks}

\section{PRODUCTION STARTUP}

\section{A. Design and Tooling Setup}

Initial product "models" will be designed for development of the PDC line of work. Tooling and Mold making of these "models" will be developed and produced. This process will be implemented by Professor Anderson and Mr. Greenham.

\section{B. Production Start Up}

Initial production start up will be coordinated and implemented by Mr. Greenham. This will include the technical, production and marketing development of a line of work to be offered for sale to the currently identified markets.

Includes: Clay Body Chemistry and Development

Glaze Chemistry and Development

Initial Production Runs

Firing of Ware

Advertising Creation

Sales Coordination

As production expands Mr. Greenham will coordinate all aspects and personnel requirements for the continued development of the PDC reporting to Professor Anderson and the Division Chair.

\section{Market Development}

Product will initially be developed for the W.V.U. Alumni and Book Stores with some work additionally being offered for sale through the Tamarack Crafts Store. 
Advertising Creation and Sales Coordination will be directed and / or implemented by the Department.

\section{PHASE 3.}

\section{PROGRAM EXPANSION}

Proposed Time Frame - 1 - 2 years

The program expansion area is the key to the success of the ultimate goals of the PDC program both on scholastic and entrepreneurial levels. It will, through expanded market development and production volume allow the program to gain an impressive reputation scholastically and serve as a unique educational model by supplementing it's own existence through income generated by the program.

The program expansion will be accomplished through, but not limited to, the inclusion of the following areas of development:

- The development of limited edition and / or higher volume product offerings designed by students, faculty and visiting artists in both ceramics and cross media disciplines.

- Program expansion to include the existing Chinese exchange program.

- Development of a National Apprentice program.

- Expanded marketing through National Trade Show participation.

- Catalog design and development in cooperation with the graphic arts departments.

- Marketing expansion to include the existing print media collection.

- Cooperative program and production expansion to include regional industry.

- Packaging design through interdepartmental participation.

- Business and Marketing development in cooperation with Businesses and Communication departments.

\section{Funding Request}

Funding in the amount of $\$$ is requested as "Seed Money" to begin the PDC program in earnest for a period of 12 months. These funds would carry the 
PDC through Phases 1-2 and into Phase 3 of the program's development, at which time a self sustaining cash flow can be realized. The "Seed Money" would be utilized specifically for; the full time salary of the Director position, additional part time support staff, and additional equipment and material needs as per the following breakdown budget:

Directors Salary - 12 month $\quad 60 \%$

Production Personnel P/T - 12 month $\quad 20 \%$

Additional Equipment / Materials $\quad 20 \%$

We are confident, that upon the completion of a one year period, the PDC could be financially self sufficient in it's continued operation and anticipate that revenues would allow further expansion of the program to assure multi-faceted benefits to not only the CCA Division of Art but the University as a whole. 
Appendix- $B$

\section{ABOUT THE AUTHOR}

Jeff Greenham is a ceramic artist and a W.V.U. 2002 M.F.A. candidate. He received his B.F.A. in 1977 from The School for American Crafts at Rochester Institute of Technology in Rochester, NY.

From 1977 to 1999 Mr. Greenham worked as a professional potter and has managed or owned several ceramic studio and industrial operations. He has also worked as a professional consultant dealing in technical, organizational and business advisement for artists, industry and non-profit arts organizations nationally.

He has been head of the ceramics Department at the Chautauqua School of Art, Chautauqua, NY since 1977 and current lives in Morgantown, WV with his wife Janet and their cat Chloe. 


\section{GLOSSARY}

Dearing Extruder: A machine used to blend and de-air wet, plastic, clay mixtures following their initial. Commonly known as a pug mill this machine is an important process for clay preparation in the use of Jigger / Jolly and Hydraulic Pressing processes.

Hydraulic Pressing: The molding of wet, plastic, ceramic clay by semiautomatic mechanical hydraulic plastic pressing of shapes with permeable dies. Gypsum cement (plaster) is commonly used for the molds. Instant release of the pressed shape is obtained by means of fluid pressure forced through the permeable die by compressed air.

Jiggering / Jolly: The molding of wet, plastic, ceramic clay by spreading the clay into a rotating plaster mold by means of a profile tool. Jiggering contours the inside of the form with the profile tool while the mold contours the outside. Jollying reverses the process with the profile tool shaping the outside of the form and the mold shaping the inside. In both cases forms are generally limited to open shapes such as bowls, cups and plates.

Slip Casting: The molding of ceramic shapes by pouring a liquid clay mixture into a plaster mold that absorbs water. As the water is absorbed, a layer of ceramic particles is deposited onto the mold, forming such hollow items as teapots and vases. The excess liquid is then poured out of the mold and the piece is removed in a damp but stable consistency. 


\section{BIBLIOGRAPY}

American Ceramic Society Web Page, http://www.ceramic.org, 2001

Anderson, Professor Robert, (Information Source), November, 2001

Baker, Jerry, "No Childs Play: Berea College and the Appalachian Hand Craft Revival", Sunshine Artist, 1998

Berea College Web Site, 2002, http://www.berea.edu/

Berea Crafts Online Catalog, 2002, http://www.bereacrafts.com

Campbell Studios, Inc., Catalog, (Bill Campbell, Campbell Studios Inc, Cambridge Springs, PA)

2000

Carney, Margret, "Charles Fergus Binns: The Father of American Studio Ceramics",(Hudson Hills Press, NY,NY),1998

Ceramics Monthly Web Page, http://www.ceramicsmonthly.org, 2001

"CODA Survey Results", The Crafts Report, (Wilmington, DE), May, 2001

Cooper, Emmanuel, "Ten Thousand Years of Pottery", (University of

Pennsylvania Press, Philadelphia, PA), 2000

Cuff, Yvonne Hutchinson, "Ceramic Technology for Potters and Sculptors", (University of Pennsylvania Press, Philadelphia, PA),1996

Edgecomb Potters, Catalog, (Richard Hilton, Edgecomb Potters, Edgecomb, ME), 2000

Graphicstudio at U.S.F. Web Site, 2001, http://www.graphicstudio.usf.edu

Held, Peter, "A Ceramic Continuum: Fifty Years of the Archie Bray Influence", (University of Washington Press, Seattle, WA), 2001

Homer Laughlin Inc. Web Site, http://www.homerlaughlin.com

Levin, Elaine The History of American Ceramics, (Harry N. Abrams, Inc. ,NY,NY)) 1998

National Council on the Education of the Ceramic Arts On site Interviews, 2001 \& 2002 conferences 
National Conference on the Education of the Ceramic Arts, Ceramics program database,

http://www.nceca.net/schools.html

Peterson, Susan, "Contemporary Ceramics", (Watson-Guptill Publications, NY, NY), 2000

Pottery Production Practices, (Business News Publications, Troy, MI.), March, 2000

Rutgers Center for Innovative Print and Paper Web Page, 2001

http//www.rcipp.rutgers.edu/default.html

Tabor, Sandy, Graphistudio at U.S.F., Press Release, 3/18/99,

http://www.graphicstudio.usf.edu/news

Tulane University Web Site, 2001, http://www.2.tulane.edu/about_history.cfm

Schultz, Dr. Bernard, Dean, W.V.U. College of Creative Arts, Interview, October, 2001

Strategic Plan 2001-2006, Draft, (College of Creative Arts, West Virginia

University, Morgantown, WV), 2001

Weete, John, D., "Overview of Research at WVU" (WVU, Research Corp., Morgantown, WV)

http://www.wvu.edu/ research/research-plan.html, 2001

WVU Mission Statement, http://www.wvu.edu/vision.html, 2001

WVU President's State of the University Address,

http://www.wvu.edu/ presoffc/sofu, 2000.htm,

Warford, Malcom L. "Coopting the Counter Culture: the Making and Unmaking of a Radical Tradition at Berea College (S.I.:s.n.)1974 